\title{
Speciation and Bioaccessibility of Arsenic in Rice and Its Implication in Risk Assessment
}

\author{
Meihui Li \\ South China Normal University \\ Xiaoyuan Guo \\ University of Macau \\ Nihong Wen \\ South China Normal University \\ Zijun Gan \\ South China Normal University \\ Yanru Huang \\ South China Normal University \\ Yuanbo Zhang \\ South China Normal University \\ Yuan Kang \\ South China Normal University \\ Lixuan Zeng ( $\sim$ zenglx@scnu.edu.cn ) \\ South China Normal University
}

\section{Research Article}

Keywords: As speciation, bioaccessibility, cooking method, risk assessment, rice, hazard quotient

Posted Date: October 26th, 2021

DOI: https://doi.org/10.21203/rs.3.rs-950009/v1

License: (c) (i) This work is licensed under a Creative Commons Attribution 4.0 International License. Read Full License 


\section{Abstract}

Numerous studies have studied the health risk assessment of human exposure to As or bioaccessible As via rice intake, however, the bioaccessibility of different As species in rice is seldom reported. In the present study, 31 rice samples were collected from markets or individual growers to investigate the speciation and bioaccessibility of As. Five different species ( $\mathrm{As}^{\square}, \mathrm{As}^{\mathrm{V}}$, DMA, MMA and AsB) were detected in rice samples from different regions, among which $A s^{\square}$ accounted for the largest proportion (62.95\% in average), followed by DMA and $A s^{V}$. In addition, the cooking method could facilitate the release of As from rice into gastric and intestinal juice, and subsequently increase the bioaccessibility of As. The bioaccessibility of inorganic As in cooked rice ranged from $71.83 \%$ to $100 \%$, and that of organic As ranged from $31.69 \%$ to $61.04 \%$. Noncarcinogenic and carcinogenic risk assessment of children and adults exposure to As via rice intake considering the bioaccessibility of cooked rice was carried out. The hazard quotient $(\mathrm{HQ})$ of iAs and total As for children ranged from 0.21 to 1.61 and 0.48 to 2.26 , respectively, while those for adults ranged from 0.12 to 0.88 and 0.26 to 1.23 , respectively. Incremental lifetime cancer risk (ILCR) for children and adults ranged from $9.57 \times 10$ 5 to $7.25 \times 10^{-4}$ and $5.21 \times 10^{-5}$ to $3.95 \times 10^{-4}$, respectively. The results of risk assessment indicated that children would face a higher health risk than adults when they took the same type of rice as their staple food.

\section{Introduction}

As the most important food in the world and the staple food of half the world's population, rice accounts for $70 \%$ of the human calorie intake of people in developing countries. Basing on a special cultivated condition of planting in flooded soil, rice develops a characterization of higher adsorption of toxic elements compared to xerophyte, becoming much easier to accumulate arsenic (As) and its different species (Ma et al. 2016). As a result, dietary intake is considered to be one of the main ways of As exposure to human and researches about As in rice is attracting more and more attentions (Lan et al. 2014; Schoof et al. 1999).

As a toxic nonmetallic element, As exposure through dietary pathways can lead to serious health problems, including various kinds of cancer (skin cancer, bladder cancer, lung cancer, etc.) and non-carcinogenic health risks such as skin diseases, cardiovascular diseases, and diabetes. The primary composition of arsenic speciation in rice includes arsenite (As $\left.{ }^{\prime \prime \prime}\right)$, arsenate (As $\left.s^{\vee}\right)$, monomethylated arsenic (MMA), dimethylarsine (DMA), arsenic choline (AsC), arsenobetaine (AsB), etc. (Nookabkaew et al. 2013; Lin et al. 2015). Inorganic arsenic (iAs) (consists of of As ${ }^{\text {III }}$ and As ${ }^{\vee}$ ) is considered as the most toxic speciation of As, being classified into class 1 of non-threshold carcinogen. Compared to iAs, lower toxicity of organic arsenic species like MMA and DMA was oberved, and the toxicity was decreased as the following trend: $\mathrm{As}^{\mathrm{III}}>\mathrm{As} \mathrm{s}^{\mathrm{V}}>\mathrm{MMA}>\mathrm{DMA}$ (Halder et al. 2014; Zhu et al. 2017; Kumarathilaka et al. 2019). (ASC and ASB are often considered to be non-toxic to human body.)

During the past decades, the contamination and potential toxicity from As in rice have raised the attentions from numerous researchers around the world. Assessing the health risk of As in rice to people who regard rice as staple food has become the main way to evaluate the threaten from rice As to human (Juhasz et al. 2006; Kumarathilaka et al. 2019; Sharafi et al. 2019). However, health risk assessment referring to bioaccessibility of total As and As speciation is seldom reported. In general, the total concentration of As in rice is often used as an index to evaluate the As contamination of rice, but the total amount of As in rice cannot reflect the actual amount of As available for gastro-intestinal absorption after digestion, which could result in higher estimation of health risk (Zhuang et al. 2009). Bioaccessibility, which represents the ratio of contaminants released from the food matrix in digestive juice through the process of gastrointestinal digestion to the total content of contaminants, should be taken into account when performing risk assessent. In vitro simulation of human gastrointestinal digestion which can simulate the enzymatic and physicochemical processes of human digestive tract is a better way for studying bioaccessibility compared to in-vivo test with longer experimental cycle and higher expense (Kumarathilaka et al. 2019). Previous studies have shown that in-vitro simulation can predict the relative in-vivo utilization of heavy metals (Pan et al. 2016). Researchers have also pointed out that cooking method might influence the bioaccessibility of total As in rice, as well as the total As concentration (Zhuang et al. 2016). However, there are limited studies investigating the effect of cooking methods on the bioaccessibility of different As species. To clarify the bioaccessibility of different As species is important to perform an accurate risk assessment of human exposure to As via rice intake due to the various toxicity of different As species.

In the present research, the main objective was (1) to measure the total amount of As and six typical As species in 31 rice samples; (2) to evaluate the effects of cooking methods on the bioaccessibility of different As species in rice by an in-vitro simulated digestion; (3) to perform a health risk assessment considering the bioaccessibility of As.

\section{Materials And Methods}

\subsection{Chemicals and Regents}

Standard rice sample with known elemental content was purchased from NCS Testing Technology Co., Ltd. (Beijing, China). Standards of each arsenic specie including arsenite $\left(A s^{I I I}\right)$, arsenate $\left(A s^{\vee}\right)$, monomethylated arsenic (MMA), dimethylarsine (DMA), arsenic choline (AsC) and arsenobetaine (AsB) were all purchased from National Institute of Metrology (Beijing, China).

\subsection{Sample Selection}


Rice samples were brought from local markets or individual growers, and there were 31 types of rice samples planted from different places in present study (29 rice samples from Guangdong, Hunan, Hubei and Hei Longjiang province, 2 rice samples from Japan). Among them, six rice samples (3 samples from mining area, Da baoshan in Guangdong province and other 3 samples from Foshan in Guangdong province, Changde in Hunan province, and Ha Erbin in Hei Longjiang province, respectively) were selected to study the effect of cooking method on the bioaccessibility of arsenic.

\subsection{Preparation and Experimental Procedure}

\subsubsection{Sample Preparation and Cooking Methods}

For preparation of raw rice, rice samples were freeze-dried, ground with a grinder and sieved through a 60-mesh sieve. To prepare the cooked rice, rice samples were put in the beaker with a ratio of rice and ultrapure water as 1:1.5, heated in water bath for 30 minutes. For the high-pressure steamed rice, the rice samples were cooked by a pressure cooker under the high pressure of 170-180 kpa for 20 minutes with the rice-water ratio of 1:1.5. The cooked rice was also freeze-dried, ground, and sieved through a 60-mesh sieve.

\subsubsection{Determination of total arsenic concentration}

Briefly, $0.5 \mathrm{~g}$ of prepared rice sample was placed in a PTFE digestion tube with $10 \mathrm{ml}$ concentrated $\mathrm{HNO}_{3}$ added for preliminary digestion under $120^{\circ} \mathrm{C}$ for $30 \mathrm{~min}$. The mixtures were then transferred into a microwave digestion system (Mars 6, CEM Corp., USA) for further heating $30 \mathrm{~min}$. After cooling to room temperature, the remaining mixtures were diluted to a total volume of $25 \mathrm{ml}$, and then filtered through $0.22 \mu \mathrm{m}$ syringe filters, waiting for instrumental analysis. The total As concentration of rice samples was determined by an ICP-QMS (7900, Agilent Technologies Inc., USA)

\subsubsection{Determination of arsenic speciation}

One gram of prepared rice sample was put into $50 \mathrm{ml}$ sterilized plastic centrifuge tube with the addition of $20 \mathrm{ml} 0.15 \mathrm{~mol} / \mathrm{l} \mathrm{HNO}{ }_{3}$ solution and placed overnight. The centrifuge tubes with rice samples were then extracted in a $9^{\circ} \mathrm{C}$ incubator for $2.5 \mathrm{~h}$, and shaken for $1 \mathrm{~min}$ every $0.5 \mathrm{~h}$. After the extraction, these samples were cooled to room temperature and then centrifuged at $8000 \mathrm{r} / \mathrm{min}$ for $15 \mathrm{~min}$. The liquid phase of the products after centrifugation was recovered by filtering through $0.22 \mu \mathrm{m}$ syringe filters prior to instrumental analysis.

The qualification and quantification of As speciation were conducted by HPLC (1260, Agilent Technologies Inc., USA) coupled with ICP-QMS (7900, Agilent Technologies Inc., USA) system. PRP-X100 anion exchange column ( $250 \times 4.1 \mathrm{~mm}, 10 \mu \mathrm{m}$; Hamilton Co., USA) was used to separate six different species of As by a binary mobile phase system (water: $25 \mathrm{mM}$ diammonium hydrogen phosphate $\left(\left(\mathrm{NH}_{4}\right)_{2} \mathrm{HPO}_{3}\right)$ solution $(\mathrm{pH}=9)=100: 0$ (0 3.5 min), 100:0 0:100 (3.5 7min), 0:100 (7 15 min), 0:100 100:0(15 16 min), 100:0(16 20 min)) at the flow rate of $1 \mathrm{ml} / \mathrm{min}$.

\subsubsection{In Vitro Digestion Simulation}

Two-gram prepared rice sample and $30 \mathrm{ml}$ simulated gastric juice were mixed in a $50 \mathrm{ml}$ centrifuge tube. The preparation of simulated gastric juice was described as previously (Pan et al. 2016). The mixture was shaken in a constant temperature oscillation incubator at $180 \mathrm{rpm}$ for 1 hour under $37^{\circ} \mathrm{C}$. The simulated digestive products were then centrifuged, and the liquid phase was collected. The collected sample was filtered through 0.22 $\mu \mathrm{m}$ syringe filters before instrumental analysis.

Intestinal digestion was conducted after stomach digestion. $\mathrm{NaHCO}_{3}$ was added into the mixtures to adjust the $\mathrm{pH}$ to 7 , and pancreatic enzyme and bile salt were then added to simulate intestinal digested environment (Pan et al. 2016). The mixtures were then incubated in a shaker at 180 rpm for 4 hours under $37^{\circ} \mathrm{C}$. The intestinal digestive solution was collected by centrifugation, and the collected sample was filtered through 0.22 $\mu \mathrm{m}$ syringe filters prior to instrumental analysis.

\subsection{Health risk assessment of arsenic in rice}

\subsubsection{Non-carcinogenic health risk assessment}

To assess the potential non-carcinogenic risk of human exposure to As via rice intake, HQ was calculated by the following equation (USEPA, 2011):

$$
\begin{gathered}
T H Q=\frac{A D D}{R f D}(1) \\
A D D=\frac{C \times B \times \operatorname{IngR\times EF\times ED}}{B W \times A T}(2)
\end{gathered}
$$

Where RfD represents the oral reference dose of iAs (inorganic As: $0.3 \mu \mathrm{g} / \mathrm{kg} \cdot$ day), C stands for the concentration of As in rice ( $\mu \mathrm{g} / \mathrm{kg}$ ), B represents the bioaccessibility of As in rice, IngR is the ingestion rate $(0.5 \mathrm{~kg} /$ day for adults, $0.3 \mathrm{~kg} /$ day for children and a proportion of $1: 3$ from raw rice to cooked rice was used) (Xiang et al. 2017), EF refers to the exposure frequency (365 days/year), ED is the exposure duration (years), BW represents the body weight (63.7 kg for adults and $20.82 \mathrm{~kg}$ for children) (Wang et al., 2020), and AT stands for averaging time (days). 


\subsubsection{Carcinogenic health risk assessment}

The method of Incremental Lifetime Cancer Risk (ILCR) was applied in carcinogenic health risk assessment of arsenic in rice according to equation (3) as follows (Sharafi et al. 2019):

$$
I L C R=A D D \times C S F(3)
$$

Where CSF refers to the Cancer Slope Factor of iAs $\left(1.5^{\times} 10^{-3} \mathrm{BW} \mathrm{kg} \cdot \mathrm{day} / \mu \mathrm{g}\right)($ USEPA 2011$)$.

\subsection{Quality control and assurance}

For determination of total As and As speciation, each rice sample was conducted in triplicate. During the whole experiment, to assure the quality of each instrumental analysis, the procedure blank, and standard rice sample (contained known amount of iAs and oAs) were run with each batch of 8 samples, and the average recovery of total As amount, iAs amount and oAs amount were $95.31 \pm 2.77 \%, 97.47 \pm 1.92 \%$ and $95.52 \pm 4.11$, respectively. The limitations of detection (LODs) of AsC, AsB, As ${ }^{\prime \prime \prime}, A s^{V}$, DMA and MMA were 0.28, 1.56, 0.39, 0.41, 0.18 and 0.14 $\mu \mathrm{g} / \mathrm{kg}$, respectively, while the LOQs of them were $0.94,5.20,1.31,1.38,0.61$ and $0.47 \mu \mathrm{g} / \mathrm{kg}$, respectively.

\subsection{Statistical analysis}

SPSS software (Statistical 23, IBM Inc., USA) was used to perform analysis of variance for comparing the significant difference of As concentration among sample locations and cooking methods. Excel (365, Microsoft Coro., USA) and Origin (2019b, Originlab Corp., USA) were used to generate relevant tables and figures.

\section{Result And Discussion}

\subsection{As speciation in rice}

According to table. 1, As concentration in the rice sample ranged from 44.25 to $206.91 \mu \mathrm{g} / \mathrm{kg}$, with the average of $117.35 \mu \mathrm{g} / \mathrm{kg}$, and iAs in all samples were lower than the iAs standard in Chinese national food safety standard GB2762-2017 (0.2mg/kg) Among four sampled provinces in China, Guangdong had the highest amount of total As in rice, ranging from 105.5 to $206.91 \mu \mathrm{g} / \mathrm{kg}$, with the average of $131.11 \mu \mathrm{g} / \mathrm{kg}$, while Hunan province had the lowest As in rice ranging from 44.25 to $176.77 \mu \mathrm{g} / \mathrm{kg}$ with the average of $94.56 \mu \mathrm{g} / \mathrm{kg}$. It should be noted that the total concentration of As in rice samples from mining areas in Da Baoshan was similar with other samples, possibly due to the environmental remediation by local government during the past years (Cao et al. 2020).

Figure. 1 shows the average percentage of each As speciation to the total As amount, and the proportion was decreased as follows: As ${ }^{\square}$ DMA > $A s^{\vee}>M M A>A s B$. Inorganic arsenic (iAs) was the main component of As speciation in rice, consist of $A s^{\square}(62.95 \%)$ and $A s^{\vee}(8.47 \%)$, accounting for $71.42 \%$, which was consistent with the result found by Calatayud (Calatayud et al. 2018). Organic arsenic (oAs) accounted for relatively low proportion (28.58\%) of total As. DMA was the main component of oAs, accounting for $92.76 \%$, and followed by MMA and ASB.

\subsection{In vitro bioaccessibility of As in rice}

There were significant differences among total As concentration treated by different cooking methods $(P<0.001)$, and cooking method could significantly reduce the As concentration in rice, which was consistent with the previous findings (Goodman 2010). Compared with raw rice, steaming can reduce the total As amount in rice ranging from $10.02 \% \varangle 22.3 \%$, while the total amount of As decreased under high pressure ranged from $23.02 \% \sim 34.11 \%$. According to previous research conducted by Natio, etc. (Naito et al. 2015), after washing with deionized water for 3 times, the total arsenic content in white rice and brown rice decreased to $81 \% \sim 84 \%$ and $71 \% \sim 83 \%$ respectively, demonstrating that the potential dissolution of As during the process of cooking is able to affect the total amount.

Processing rice samples with different ways of cooking can not only affect the total concentration of As but also its bioaccessibility. Rice streamed under ordinary pressure and high pressure had higher bioaccessibilities of As than raw rice both in the stages of gastric and small intestinal tract. Regardless of the cooking methods, the bioaccessibilities of As in rice samples all had an increased trend from gastric stage to intestinal stage due to a damage on rice construction caused by cooking which made it easier for As to be released, similar to the findings of Mihucz and Sharafi (Mihucz et al. 2010; Sharafi et al. 2019). Some studies performed the risk assessment of human exposure to As via rice intake based on the content of As in raw rice (Brandon et al. 2014; Chen et al. 2016; Li et al. 2018), but the variability of total As or bioacessibility observed between the rice and cooked rice in the present study indicated that cooking would significantly influence the As exposure and should be considered in the risk assessment.

It can be seen from figure. 4 that As ${ }^{\text {III }}$ was the main component in both undigested and digested rice. For the organic As (oAs), the main component before digestion was DMA and MMA. After gastrointestinal digestion, it can be seen from the figure that the organic species of As (AsC) could be 
detected which didn't exist in undigested rice samples and showed similar concentration with DMA, which might be due to a chemical transition on speciation caused by digestion.

In simulated gastric digestion, the bioaccessibility of iAs in cooked rice ranged from $59.26-89.53 \%$, and bioaccessibility of oAs ranged from 17.05-46.29\%, while in small intestinal digestion, the bioaccessibility of iAs ranged from $71.83-100 \%$, and that of oAs ranged from $31.69-61.04 \%$. More details of bioaccessibility of different As species can be observed in table. 2. Above half of iAs could be released in the gastric phase, possibly due to that iAs can be adsorbed or bind to the proteins of rice endosperm cells (Sanz et al. 2007; Moore et al. 2010), and the acidic gastric juice can be able to desorb the iAs from the protein in rice (Goodman 2010). In addition, the bioaccessibility would be elevated after intestinal phase. The simulated intestinal juice contains pancreatic enzymes and bile salts. These enzymes can break down polysaccharides into monosaccharides,and further cut the protein into free amino acids and small peptides with a chain length of 2-6 amino acid residues, which can facilitate the release of iAs from rice into intestinal juice (Cabañero et al. 2004). Through an in-vivo investigation by feeding swine with cooked rice, Juhasz, et al. found out that the bioavailability of As in rice was about $89 \%$ (Juhasz et al. 2006). A series of studies conducted by Sun et al. found that the bioaccessibility of soluble As in cooked rice during gastrointestinal digestion ranged from 77-87\% (Sun et al. 2012), while Laparra et al. showed that the bioaccessibility of As in cooked rice ranged from 63-99\% (Laparra et al. 2005). The bioaccessibility of iAs obtained in this study showed similar result with the mentioned results. It is noteworthy that the bioaccessibility of iAs in different rice was $32.35 \%$ higher than that of oAs regardless of gastric tract or small intestinal tract, which is consistent with the conclusions in the previous literatures (Juhasz et al. 2006; Signes-Pastor et al. 2012), revealing that iAs is more easily bioavailable than oAs, based on its potentially highly efficient diffusion in digestive juice.

\subsection{Assessment of human non-carcinogenic and carcinogenic risk of As in rice}

According to table.3, the present result showed that the ADDs of total Arsenic for adults in steamed rice ranged from $0.18 \sim 0.35 \mu \mathrm{g} / \mathrm{kg} \cdot \mathrm{d}$, while ADDs of rice steamed under high pressure ranged from $0.19 \sim 0.34 \mu \mathrm{g} / \mathrm{kg} \cdot \mathrm{d}$. The ADDs of total Arsenic in steamed rice for children ranged from $0.33 \sim 0.63 \mu \mathrm{g} / \mathrm{kg} \cdot \mathrm{d}$, while ADDs of rice steamed under high pressure ranged from $0.34 \sim 0.63 \mu \mathrm{g} / \mathrm{kg} \cdot \mathrm{d}$. Considering the high toxicity induced by iAs, ADD of iAs for evaluating risk should be individually estimated. The ADDs of iAs in rice steamed under ordinary pressure and high pressure for adults were around $0.17 \sim 0.26 \mu \mathrm{g} / \mathrm{kg} \cdot \mathrm{d}$ and $0.16 \sim 0.24 \mu \mathrm{g} / \mathrm{kg} \cdot \mathrm{d}$, respectively. The ADDs of iAs in rice steamed under ordinary pressure and high pressure for children were around $0.32 \sim 0.48 \mu \mathrm{g} / \mathrm{kg} \cdot \mathrm{d}$ and $0.29 \sim 0.44 \mu \mathrm{g} / \mathrm{kg} \cdot \mathrm{d}$, respectively. Although the bioaccessibility of iAs in rice cooked by high pressure was higher than that by ordinary pressure, the loss of As amount was more in high pressure which resulted in that the calculated bioaccessibility value in those two cooking methods were similar and subsequently the ADDs calculated were similar. THQs for children regardless of cooking methods ranged from $1.10 \sim 2.11$ (As) and $0.98 \sim 1.61$ (iAs), while THQs for adults ranged from $0.60 \sim 1.15$ (As) and $0.53 \sim 0.88$ (iAs). The range of ILCR for children was from $4.40 \sim 7.25 \times 10^{-4}$, while that for adults was from $2.40 \sim 3.95 \times 10^{-4}$.

In order to convenient use of established bioaccessibility value, the remaining As and bioaccessibility after cooking were integrated into a combined bioaccessibility and it could be directly used to perform risk assessment when the As or iAs was detected in raw rice sample (Table. 4).

It can be easily observed from figure. 5 that health risk of As in rice was similar for different cooking method. For children, the average THQ of total As in rice samples was higher than 1 and $68 \%$ of rice samples resulted in that their corresponding THQ values were bigger than 1 . For adults, only $2 \%$ of all the THQ regardless of As or iAs was lower than 1. It indicated that children would face a higher non-carcinogenic risk than adults when they took the same type of rice as their staple food.

The incremental lifetime cancer risk (ILCR) is acceptable when it is less than $1 \times 10^{-4}$. (Cao et al. 2015). The present results showed that the ILCR of 30 of the 31 rice samples exceeded $1 \times 10^{-4}$, indicating a certain level of carcinogenic risk to human whose staple food was rice. The average ILCR of 31 types of rice samples for adults is $2.26 \times 10^{-4}$, while the average ILCR for children is $4.15 \times 10^{-4}$, representing that children might bear higher carcinogenic risk compared to adults when taking rice as staple food. It should be noted that the rice sample collected in the present study belonged to indica rice and japonica rice, and the established bioaccessibility value could not be applied in glutinous rice. In addition, other elements such as calcium and ferric ion would influence the release of As from rice and the enteric microorganisms might affect the transformation between the inorganic and organic As, which should be investigated in future work.

\section{Conclusion}

The concentration of different speciation in rice samples was decreased in the order: $A s^{\square}>D M A>A s \vee>M M A>A s B$, and inorganic arsenic accounted for $71.42 \%$ of total As. In the in-vitro digestion simulation, the bioaccessibility of As in rice after small intestinal digestion was higher than that obtained after gastric digestion. Cooking method could increase the bioaccessibility of As. The bioaccessibility of iAs in cooked rice ranged from 71.83-100\%, and that of oAs ranged from 31.69-61.04\%, which indicated that iAs in rice might be eaiser to be ingested by human body than oAs. Risk assessment indicated tha the average THQ of total As in rice samples was higher than 1 and $68 \%$ of rice samples resulted in that their corresponding THQ values were bigger than 1 for children. For adults, only $2 \%$ of all the THQ regardless of As or iAs was lower than 1 . The average ILCR for adults is $2.26 \times 10^{-4}$, while the average ILCR for children is $4.15 \times 10^{-4}$, which indicated that children who take rice as staple food may potentially bear more health risk than adults. 


\section{Declarations}

\section{- Ethics approval and consent to participate}

Not applicable

\section{- Consent for publication}

Not applicable

\section{- Availability of data and materials}

All data generated or analysed during this study are included in this published article.

\section{- Competing interests}

The authors declare that they have no competing interests.

\section{- Funding}

This study was supported by grants from the Science and Technology Planning Project of Guangdong Province, China (Grant No. 2014A020216036).

\section{- Authors' contributions}

Lixuan, Zeng; Yuan Kang: Conceptualization;

Meihui Li; Xiaoyuan Guo: Data curation;

Meihui Li: Formal analysis;

Yuan Kang, Lixuan Zeng: Funding acquisition;

Meihui Li, Xiaoyuan Guo, Nihong Wen, Zijun Gan, Yanru Huang, Yuanbo Zhang: Investigation;

Xiaoyuan Guo: Methodology;

Lixuan Zeng, Yuan Kang: Project administration;

Lixuan Zeng, Yuan Kang: Resources;

Meihui Li, Xiaoyuan Guo: Software;

Lixuan Zeng, Yuan Kang: Supervision;

Nihong Wen, Zijun Gan, Yanru Huang, Yuanbo Zhang: Validation;

Meihui Li, Xiaoyuan Guo: Roles/Writing - original draft;

Meihui Li, Yuan Kang: Writing - review \&editing

\section{- Acknowledgements}

Not applicable

\section{References}

1. Brandon EF, Janssen PJ, de Wit-Bos L (2014) Arsenic: bioaccessibility from seaweed and rice, dietary exposure calculations and risk assessment. Food Addit Contam A 31: 1993-2003.

2. Cabañero Al, Madrid Y, Cámara C (2004) Selenium and mercury bioaccessibility in fish samples: an in vitro digestion method. Anal Chim Acta 526: 51-61.

3. Calatayud M, Xiong C, Du Laing G, Raber G, Francesconi K, Van de Wiele T (2018) Salivary and gut microbiomes play a significant role in in vitro oral bioaccessibility, biotransformation, and intestinal absorption of arsenic from food. Environ Sci Technol 52: $14422-14435$. 
4. Cao C, Zhang S, Zhang P, Liu Y, Chen X, Wang J (2020) Status and risk assessment of heavy metal pollution in soil-vegetable system in Dabaoshan sewage irrigation area J Agro-Environ Sci 39: 1521-1531.

5. Cao S, Duan X, Zhao X, et al (2015) Health risk assessment of various metal (loid) s via multiple exposure pathways on children living near a typical lead-acid battery plant, China. Environ Pollut 200: 16-23.

6. Chen HL, Lee CC, Huang WJ, Huang HT, Wu YC, Hsu YC, Kao YT (2016) Arsenic speciation in rice and risk assessment of inorganic arsenic in Taiwan population. Environ Sci Pollut Res 23: 4481-4488.

7. Goodman BE (2010) Insights into digestion and absorption of major nutrients in humans. Adv Physiol Educ 34: 44-53.

8. Halder D, Biswas A, Šlejkovec Z, Chatterjee D, Nriagu J, Jacks G, Bhattacharya P (2014) Arsenic species in raw and cooked rice: implications for human health in rural Bengal. Sci Total Environ 497: 200-208.

9. Juhasz AL, Smith E, Weber J, Rees M, Rofe A, Kuchel T, Sansom L, Naidu R (2006) In vivo assessment of arsenic bioavailability in rice and its significance for human health risk assessment. Environ Health Perspect 114: 1826-1831.

10. Kumarathilaka P, Seneweera S, Ok YS, Meharg A, Bundschuh J (2019) Arsenic in cooked rice foods: assessing health risks and mitigation options. Environ Int 127: 584-591.

11. Lan D, Lei M, Zhou S, Liao B, Cui J, Yin N, Shen Y (2014) Evaluation of human health risks of heavy metals in rice from a mining area in southern Hunan by in vitro simulation experiment. J Agro-environ Sci 33: 1897-1903.

12. Laparra JM, Vélez D, Barberá R, Farré R, Montoro R (2005) Bioavailability of inorganic arsenic in cooked rice: practical aspects for human health risk assessments. J Agr Food Chem 53: 8829-8833.

13. Li T, Song Y, Yuan X, Li J, Ji J, Fu X, Zhang Q, Guo S (2018) Incorporating bioaccessibility into human health risk assessment of heavy metals in rice (Oryza sativa L.): a probabilistic-based analysis. J Agr Food Chem 66: 5683-5690.

14. Lin K, Lu S, Wang J, Yang Y (2015) The arsenic contamination of rice in Guangdong Province, the most economically dynamic provinces of China: arsenic speciation and its potential health risk. Environ Geochem Health 37: 353-361.

15. Ma L, Wang L, Jia Y, Yang Z (2016) Arsenic speciation in locally grown rice grains from Hunan province, China: spatial distribution and potential health risk. Sci Total Environ 557: 438-444.

16. Mihucz VG, Silversmit G, Szalóki I, De Samber B, Schoonjans T, Tatár E, Vincze L, Virág I, Yao J, Záray G (2010) Removal of some elements from washed and cooked rice studied by inductively coupled plasma mass spectrometry and synchrotron based confocal micro-X-ray fluorescence. Food Chem 121: 290-297.

17. Moore KL, Schröder M, Lombi E, Zhao FJ, McGrath SP, Hawkesford MJ, Shewry PR, Grovenor CR (2010) NanoSIMS analysis of arsenic and selenium in cereal grain. New Phytol 185: 434-445.

18. Naito S, Matsumoto E, Shindoh K, Nishimura T (2015) Effects of polishing, cooking, and storing on total arsenic and arsenic species concentrations in rice cultivated in Japan. Food Chem 168: 294-301.

19. Nookabkaew S, Rangkadilok N, Mahidol C, Promsuk G, Satayavivad (2013) Determination of arsenic species in rice from Thailand and other Asian countries using simple extraction and HPLC-ICP-MS analysis. J Agr Food Chem 61: 6991-6998.

20. Pan W, Kang Y, Zeng L, Zhang Q, Luo J, Wong MH (2016) Comparison of in vitro digestion model with in vivo relative bioavailability of BDE209 in indoor dust and combination of in vitro digestion/Caco-2 cell model to estimate the daily intake of BDE-209 via indoor dust. Environm Pollut 218: 497-504.

21. Sanz E, Munoz-Olivas R, Camara C, Sengupta MK, Ahamed S (2007) Arsenic speciation in rice, straw, soil, hair and nails samples from the arsenic-affected areas of Middle and Lower Ganga plain. J Environ Sci Health 42: 1695-1705.

22. Schoof R, Yost L, Eickhoff J, Crecelius E, Cragin D, Meacher D, Menzel, D (1999) A market basket survey of inorganic arsenic in food. Food Chem Toxiol 37: 839-846.

23. Sharafi K, Nodehi RN, Mahvi AH, Pirsaheb M, Nazmara S, Mahmoudi B, Yunesian, M (2019) Bioaccessibility analysis of toxic metals in consumed rice through an in vitro human digestion model-Comparison of calculated human health risk from raw, cooked and digested rice. Food Chem 299: 125126.

24. Signes-Pastor AJ, Al-Rmalli SW, Jenkins RO, Carbonell-Barrachina ÁA, Haris PI (2012) Arsenic bioaccessibility in cooked rice as affected by arsenic in cooking water. J Food Sci 77: T201-T206.

25. Sun GX, Van de Wiele T, Alava P, Tack F, Du Laing G (2012) Arsenic in cooked rice: effect of chemical, enzymatic and microbial processes on bioaccessibility and speciation in the human gastrointestinal tract. Environ Pollut 162: 241-246.

26. USEPA (2011) Integrated risk information system. US Environmental Protection Agency, Washington DC.

27. Wang L, Wang H, Zhang B, Popkin BM, Du S (2020) Elevated fat intake increases body weight and the risk of overweight and obesity among Chinese adults: 1991-2015 Trends. Nutrients 12: 3272.

28. Xiang L, Liu P, Yang Y (2017) Radionuclide uranium contamination characteristics and health risk assessment of rice in a uranium mining area in East China. Resour Environ the Yangtze Basin 26: 419-427. 
29. Zhu YG, Xue XM, Kappler A, Rosen BP, Meharg AA (2017) Linking genes to microbial biogeochemical cycling: lessons from arsenic. Environ Sci Technol 51: 7326-7339.

30. Zhuang P, McBride MB, Xia H, Li N, Li Z (2009) Health risk from heavy metals via consumption of food crops in the vicinity of Dabaoshan mine, South China. Sci Total Environ 407: 1551-1561.

31. Zhuang P, Zhang C, Li Y, Zou B, Mo H, Wu K, Wu J, Li Z (2016) Assessment of influences of cooking on cadmium and arsenic bioaccessibility in rice, using an in vitro physiologically-based extraction test. Food Chemistry 213: 206-214.

\section{Tables}

Table 1. Detection of total As and As speciation in 31 rice samples.

$$
\text { AsC AsB DMA }
$$

MMA

$\mathrm{As}^{\mathrm{III}}$

$\mathrm{As}^{\mathrm{V}}$

Total As

\begin{tabular}{|c|c|c|c|c|c|c|c|c|c|c|c|c|c|c|c|c|c|c|c|c|}
\hline \multirow{2}{*}{$\begin{array}{c}\text { Province } \\
\text { Hunan }\end{array}$} & \multirow{2}{*}{$\begin{array}{c}\text { City } \\
\text { Zhuzhou-1 }\end{array}$} & \multicolumn{19}{|c|}{ Concentration $(\mu \mathrm{g} / \mathrm{kg})$} \\
\hline & & ND & & ND & & 17.52 & \pm & 0.35 & 1.65 & \pm & 0.17 & 58.88 & \pm & 5.34 & 10.55 & \pm & 1.43 & 110.02 & \pm & 2.18 \\
\hline & Zhuzhou-2 & ND & & ND & & 10.94 & \pm & 0.54 & 2.24 & \pm & 0.18 & 54.60 & \pm & 2.72 & 7.83 & \pm & 1.34 & 85.20 & \pm & 6.45 \\
\hline & Zhuzhou-3 & ND & & ND & & 2.80 & \pm & 0.28 & 0.52 & \pm & 0.03 & 66.74 & \pm & 0.84 & 7.95 & \pm & 0.39 & 81.88 & \pm & 40.19 \\
\hline & Zhuzhou-4 & ND & & ND & & 13.76 & \pm & 0.53 & 0.66 & \pm & 0.23 & 29.70 & \pm & 2.52 & 8.65 & \pm & 0.30 & 69.20 & \pm & 19.47 \\
\hline & Chenzhou & ND & & ND & & 22.38 & \pm & 0.79 & 2.48 & \pm & 0.28 & 12.24 & \pm & 0.99 & 5.75 & \pm & 0.30 & 44.25 & \pm & 22.31 \\
\hline & Changde & ND & & ND & & 14.79 & \pm & 1.30 & 3.57 & \pm & 2.59 & 131.62 & \pm & 2.37 & 12.56 & \pm & 9.88 & 176.77 & \pm & 0.66 \\
\hline \multirow[t]{12}{*}{ Guangdong } & $\begin{array}{c}\text { Da Baoshan } \\
\text { A }\end{array}$ & ND & & ND & & 18.86 & \pm & 0.37 & 1.98 & \pm & 0.48 & 79.91 & \pm & 18.45 & 28.36 & \pm & 9.40 & 153.30 & \pm & 5.54 \\
\hline & $\begin{array}{c}\text { Da Baoshan } \\
\text { B }\end{array}$ & ND & & ND & & 22.50 & \pm & 0.79 & 4.53 & \pm & 2.43 & 90.70 & \pm & 2.81 & 19.00 & \pm & 10.77 & 159.58 & \pm & 3.12 \\
\hline & $\begin{array}{c}\text { Da Baoshan } \\
\text { C }\end{array}$ & ND & 4.57 & \pm & 1.79 & 26.31 & \pm & 2.34 & 4.28 & \pm & 1.12 & 73.71 & \pm & 0.99 & 6.59 & \pm & 6.11 & 115.46 & \pm & 4.03 \\
\hline & Foshan & ND & & ND & & 35.23 & \pm & 3.05 & 3.69 & \pm & 0.39 & 84.75 & \pm & 1.38 & 6.91 & \pm & 1.06 & 150.50 & \pm & 6.15 \\
\hline & Foshan-2 & ND & & ND & & 47.22 & \pm & 1.00 & 4.96 & \pm & 0.71 & 53.75 & \pm & 4.76 & 6.49 & \pm & 0.24 & 134.36 & \pm & 14.95 \\
\hline & Foshan-3 & ND & & ND & & 28.98 & \pm & 0.82 & 2.89 & \pm & 0.29 & 51.43 & \pm & 1.64 & 8.95 & \pm & 0.31 & 122.81 & \pm & 19.36 \\
\hline & Shaoguan & ND & & ND & & 14.32 & \pm & 0.53 & 0.26 & \pm & 0.02 & 33.85 & \pm & 1.52 & 7.51 & \pm & 0.50 & 61.57 & \pm & 51.15 \\
\hline & Qingyuan & ND & & ND & & 17.89 & \pm & 2.45 & 1.27 & \pm & 0.25 & 32.44 & \pm & 1.06 & 12.47 & \pm & 0.08 & 76.40 & \pm & 6.60 \\
\hline & Guangzhou- & ND & & ND & & 71.95 & \pm & 2.14 & 1.13 & \pm & 0.86 & 83.22 & \pm & 6.84 & 11.03 & \pm & 0.74 & 206.91 & \pm & 41.94 \\
\hline & $\underset{2}{\text { Guangzhou- }}$ & ND & & ND & & 15.97 & \pm & 0.15 & 0.17 & \pm & 0.06 & 99.76 & \pm & 2.85 & 11.43 & \pm & 1.35 & 156.05 & \pm & 24.07 \\
\hline & Zengcheng & ND & & ND & & 40.37 & \pm & 0.61 & 1.31 & \pm & 0.48 & 59.06 & \pm & 1.75 & 5.48 & \pm & 0.35 & 122.62 & \pm & 12.73 \\
\hline & Zhongshan & ND & & ND & & 80.51 & \pm & 2.47 & 0.93 & \pm & 0.90 & 50.14 & \pm & 3.14 & 5.03 & \pm & 0.90 & 109.00 & \pm & 31.05 \\
\hline \multirow{6}{*}{$\begin{array}{c}\text { Hei } \\
\text { Longjiang }\end{array}$} & Ha Erbin & ND & 1.91 & \pm & 1.33 & 23.17 & \pm & 4.13 & 5.53 & \pm & 0.94 & 101.91 & \pm & 4.90 & 11.47 & \pm & 6.04 & 158.90 & \pm & 3.26 \\
\hline & Ha Erbin-2 & ND & & ND & & 39.84 & \pm & 2.29 & 5.07 & \pm & 0.30 & 40.97 & \pm & 5.63 & 17.47 & \pm & 0.79 & 128.91 & \pm & 22.86 \\
\hline & Ha Erbin-3 & ND & & ND & & 44.32 & \pm & 3.84 & 1.03 & \pm & 0.07 & 36.86 & \pm & 2.04 & 7.51 & \pm & 1.95 & 110.01 & \pm & 12.51 \\
\hline & Ha Erbin-4 & ND & & ND & & 35.25 & \pm & 1.65 & 0.36 & \pm & 0.28 & 75.76 & \pm & 2.26 & 6.54 & \pm & 1.01 & 133.51 & \pm & 12.51 \\
\hline & Ha Erbin-5 & ND & & ND & & 39.11 & \pm & 1.28 & 0.91 & \pm & 0.30 & 75.23 & \pm & 2.35 & 5.93 & \pm & 0.18 & 139.00 & \pm & 28.01 \\
\hline & Ha Erbin-6 & ND & & ND & & 18.91 & \pm & 1.19 & 0.31 & \pm & 0.09 & 79.39 & \pm & 1.85 & 10.37 & \pm & 0.43 & 97.55 & \pm & 78.86 \\
\hline \multirow[t]{5}{*}{ Hubei } & Jingmen-1 & ND & & ND & & 65.10 & \pm & 30.97 & 1.02 & \pm & 0.16 & 111.62 & \pm & 2.85 & 6.34 & \pm & 0.26 & 161.02 & \pm & 26.17 \\
\hline & Jingmen-2 & ND & 2.22 & \pm & 0.69 & 9.13 & \pm & 0.31 & 1.18 & \pm & 0.23 & 91.00 & \pm & 0.27 & 4.84 & \pm & 1.90 & 92.57 & \pm & 3.27 \\
\hline & Xiantao-1 & ND & & ND & & 36.61 & \pm & 0.88 & 1.65 & \pm & 1.30 & 64.83 & \pm & 0.94 & 5.84 & \pm & 0.94 & 126.24 & \pm & 5.97 \\
\hline & Xiantao-2 & ND & & ND & & 18.43 & \pm & 1.16 & 1.91 & \pm & 0.34 & 74.93 & \pm & 3.45 & 4.27 & \pm & 0.22 & 90.72 & \pm & 3.37 \\
\hline & Xiantao-3 & ND & & ND & & 4.13 & \pm & 0.07 & 0.50 & \pm & 0.16 & 63.72 & \pm & 2.24 & 6.57 & \pm & 0.42 & 93.42 & \pm & 13.93 \\
\hline \multirow{2}{*}{$\begin{array}{l}\text { Other } \\
\text { Country }\end{array}$} & Japan-1 & ND & & ND & & 15.79 & \pm & 0.18 & 0.87 & \pm & 0.46 & 42.33 & \pm & 3.18 & 5.81 & \pm & 0.45 & 66.10 & \pm & 13.97 \\
\hline & Japan-2 & ND & & ND & & 26.00 & \pm & 1.20 & 0.91 & \pm & 0.20 & 78.77 & \pm & 1.48 & 4.63 & \pm & 0.98 & 99.17 & \pm & 12.94 \\
\hline
\end{tabular}

Table 2. Bioaccessibiliy of As speciation in rice of six selected regions treated with different cooking methods. 


\begin{tabular}{lllll}
\hline DMA & MMA & As & & \\
& & 0-As & i-As \\
\hline
\end{tabular}

Bioaccessibility, \%

\begin{tabular}{|c|c|c|c|c|c|c|c|c|c|c|c|c|c|c|c|c|}
\hline \multirow[t]{11}{*}{ Steamed } & $\begin{array}{c}\text { Da Baoshan } \\
\text { Zone A }\end{array}$ & $\begin{array}{c}\text { Gastric } \\
\text { Small Intestinal }\end{array}$ & $\begin{array}{l}29.73 \\
35.30\end{array}$ & $\begin{array}{l} \pm \\
\pm\end{array}$ & $\begin{array}{l}1.68 \\
2.33\end{array}$ & $\begin{array}{l}40.50 \\
55.75\end{array}$ & $\begin{array}{l} \pm \\
\pm\end{array}$ & $\begin{array}{l}5.04 \\
1.63\end{array}$ & $\begin{array}{l}79.08 \\
79.57\end{array}$ & $\begin{array}{l} \pm \\
\pm\end{array}$ & $\begin{array}{l}4.92 \\
1.35\end{array}$ & $\begin{array}{l}18.71 \\
48.18\end{array}$ & $\begin{array}{l} \pm \\
\pm \\
\pm\end{array}$ & $\begin{array}{l}7.35 \\
5.32\end{array}$ & $\begin{array}{l}30.77 \\
37.27\end{array}$ & $\begin{array}{l}60.35 \\
71.83\end{array}$ \\
\hline & \multirow{2}{*}{$\begin{array}{c}\text { Da Baoshan } \\
\text { Zone B }\end{array}$} & Gastric & 22.66 & \pm & 5.79 & 21.08 & \pm & 3.11 & 74.83 & \pm & 8.67 & 19.53 & \pm & 6.05 & 22.34 & 68.59 \\
\hline & & Small Intestinal & 35.78 & \pm & 3.66 & 41.09 & \pm & 2.72 & 91.35 & \pm & 3.71 & 81.04 & \pm & 8.36 & 36.84 & 90.18 \\
\hline & \multirow{2}{*}{$\begin{array}{c}\text { Da Baoshan } \\
\text { Zone C }\end{array}$} & Gastric & 20.95 & \pm & 3.79 & 23.17 & \pm & 3.87 & 78.39 & \pm & 1.91 & \multicolumn{3}{|c|}{ ND } & 21.21 & 72.74 \\
\hline & & Small Intestinal & 31.97 & \pm & 0.74 & 34.94 & \pm & 1.21 & 93.07 & \pm & 1.67 & 43.57 & \pm & 4.82 & 32.33 & 89.49 \\
\hline & \multirow[t]{2}{*}{ Foshan } & Gastric & 21.01 & \pm & 1.32 & 35.49 & \pm & 5.10 & 69.66 & \pm & 2.85 & \multicolumn{3}{|c|}{ ND } & 22.27 & 64.49 \\
\hline & & Small Intestinal & 28.92 & \pm & 4.22 & 60.85 & \pm & 4.02 & 82.54 & \pm & 2.79 & 45.02 & \pm & 12.00 & 31.69 & 79.76 \\
\hline & \multirow[t]{2}{*}{ Changde } & Gastric & 14.80 & \pm & 4.74 & 31.11 & \pm & 7.17 & 61.72 & \pm & 7.59 & 25.60 & \pm & 7.62 & 17.05 & 59.26 \\
\hline & & Small Intestinal & 50.70 & \pm & 5.97 & 51.80 & \pm & 6.37 & 83.85 & \pm & 9.22 & 70.53 & \pm & 5.17 & 50.85 & 82.94 \\
\hline & \multirow[t]{2}{*}{ Ha Erbin } & Gastric & 27.16 & \pm & 8.65 & 29.59 & \pm & 3.07 & 81.33 & \pm & 3.15 & 27.81 & \pm & 2.11 & 27.75 & 75.81 \\
\hline & & Small Intestinal & 49.03 & \pm & 2.82 & 47.27 & \pm & 0.75 & 91.95 & \pm & 3.75 & 90.25 & \pm & 6.24 & 48.61 & 91.78 \\
\hline \multirow{12}{*}{$\begin{array}{l}\text { High Pressure } \\
\text { Steamed }\end{array}$} & \multirow{2}{*}{$\begin{array}{c}\text { Da Baoshan } \\
\text { Zone A }\end{array}$} & Gastric & 15.75 & \pm & 3.31 & 65.58 & \pm & 6.36 & 76.67 & \pm & 0.35 & 9.05 & \pm & 1.52 & 21.34 & 69.12 \\
\hline & & Small Intestinal & 40.67 & \pm & 6.90 & 51.24 & \pm & 0.04 & 83.46 & \pm & 14.01 & 59.45 & \pm & 5.04 & 41.86 & 80.78 \\
\hline & \multirow{2}{*}{$\begin{array}{l}\text { Da Baoshan } \\
\text { Zone B }\end{array}$} & Gastric & 30.72 & \pm & 4.33 & 48.87 & \pm & 0.22 & 93.87 & \pm & 4.26 & 22.45 & \pm & 1.69 & 32.73 & 85.96 \\
\hline & & Small Intestinal & 46.01 & \pm & 4.01 & 53.91 & \pm & 3.54 & 103.07 & \pm & 10.44 & 78.64 & \pm & 6.55 & 46.89 & 100.00 \\
\hline & \multirow{2}{*}{$\begin{array}{l}\text { Da Baoshan } \\
\text { Zone C }\end{array}$} & Gastric & 27.11 & \pm & 8.61 & 59.24 & \pm & 6.07 & 77.49 & \pm & 4.23 & 48.70 & \pm & 8.21 & 29.26 & 76.13 \\
\hline & & Small Intestinal & 32.69 & \pm & 7.44 & 69.26 & \pm & 11.65 & 92.73 & \pm & 6.00 & 84.34 & \pm & 4.10 & 35.13 & 92.33 \\
\hline & \multirow[t]{2}{*}{ Foshan } & Gastric & 29.68 & \pm & 9.52 & 60.35 & \pm & 4.59 & 82.73 & \pm & 0.71 & \multicolumn{3}{|c|}{ ND } & 31.55 & 78.10 \\
\hline & & Small Intestinal & 39.74 & \pm & 6.00 & 132.70 & \pm & 7.02 & 93.36 & \pm & 3.90 & 126.18 & \pm & 23.58 & 45.39 & 95.19 \\
\hline & \multirow[t]{2}{*}{ Changde } & Gastric & 29.73 & \pm & 0.71 & 57.14 & \pm & 5.83 & 93.20 & \pm & 2.45 & 41.27 & \pm & 7.09 & 34.50 & 89.53 \\
\hline & & Small Intestinal & 51.83 & \pm & 7.90 & 77.73 & \pm & 3.75 & 96.02 & \pm & 4.50 & 48.56 & \pm & 6.85 & 56.34 & 92.67 \\
\hline & \multirow[t]{2}{*}{ Ha Erbin } & Gastric & 19.55 & \pm & 9.45 & 65.66 & \pm & 7.69 & 86.26 & \pm & 7.88 & \multicolumn{3}{|c|}{ ND } & 28.64 & 80.43 \\
\hline & & Small Intestinal & 63.00 & \pm & 2.50 & 53.08 & \pm & 1.78 & 91.42 & \pm & 3.07 & 73.61 & \pm & 14.76 & 61.04 & 90.22 \\
\hline
\end{tabular}

Table 3. Estimated THQ and ILCR of As in rice of six regions treated with different cooking methods.

\begin{tabular}{lllll}
\hline ADD-As & ADD-iAs & ADD-As & ADD-iAs & THQ
\end{tabular}

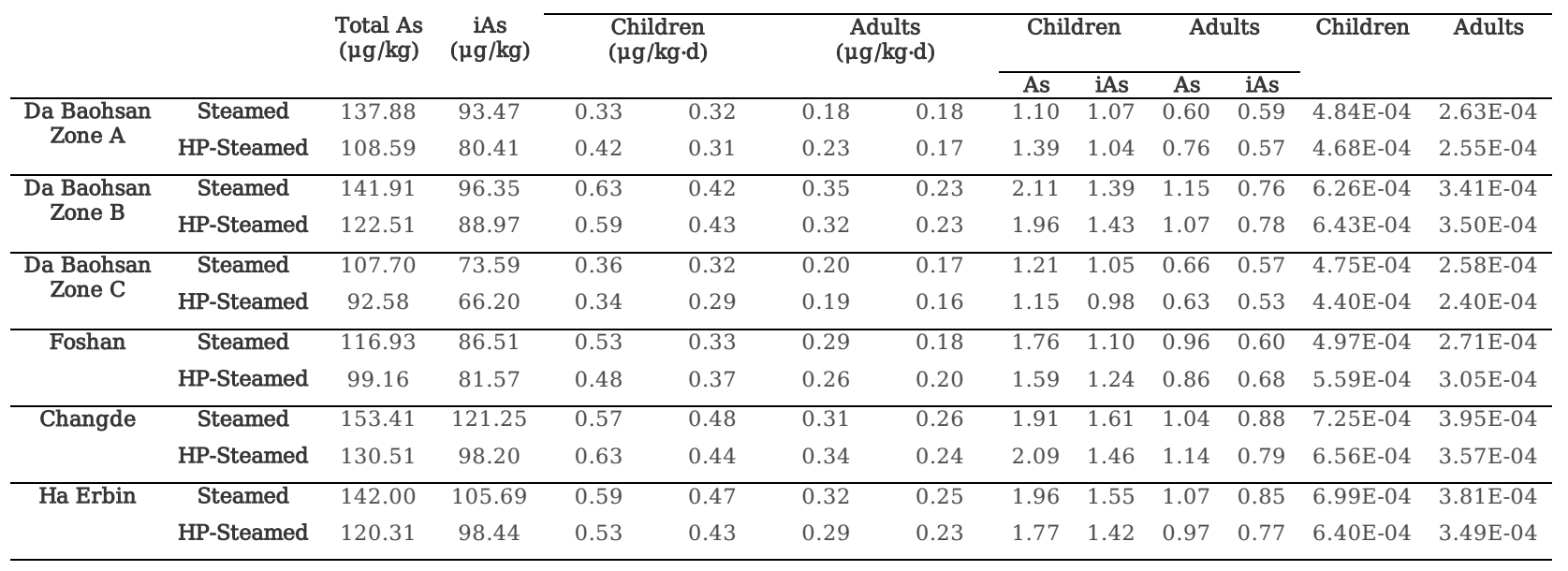

Table 4. Simulated proportions of As amount and bioaccessibility after cooking rice.

\begin{tabular}{cccc}
\hline Cooking Method & Modeled Indicator & Total As & Inorganic As \\
\hline Steamed & Amount of As (a) & $87.05 \%$ & $89.58 \%$ \\
\cline { 2 - 4 } & Bioaccessibility (b) & $78.50 \%$ & $84.33 \%$ \\
\cline { 2 - 4 } & (a) (b) & $\mathbf{6 8 . 3 3 \%}$ & $\mathbf{7 5 . 2 4 \%}$ \\
\hline HP-Steamed & Amount of As (c) & $73.34 \%$ & $80.29 \%$ \\
\cline { 2 - 4 } & Bioaccessibility (d) & $84.33 \%$ & $91.93 \%$ \\
\cline { 2 - 4 } & (c) (d) & $\mathbf{6 1 . 8 5 \%}$ & $\mathbf{7 3 . 8 1 \%}$ \\
\hline
\end{tabular}

Table 5. Health risk assessment of As in rice steamed under ordinary pressure to children and adults. 


\begin{tabular}{|c|c|c|c|c|c|c|c|c|c|c|c|c|c|c|}
\hline \multirow{4}{*}{ Steamed } & \multirow{4}{*}{ Hunan } & \multirow{4}{*}{ Zhuzhou-1 } & \multirow{3}{*}{$\begin{array}{c}\text { Total As } \\
(\mu \mathrm{g} / \mathrm{kg})\end{array}$} & \multirow{3}{*}{$\begin{array}{c}\text { iAs } \\
(\mu \mathrm{g} / \mathrm{kg})\end{array}$} & \multirow{3}{*}{\multicolumn{2}{|c|}{$\begin{array}{l}\text { Children } \\
(\mu \mathrm{g} / \mathrm{kg} \cdot \mathrm{d})\end{array}$}} & \multirow{3}{*}{\multicolumn{2}{|c|}{$\begin{array}{c}\text { Adults } \\
(\mu \mathrm{g} / \mathrm{kg} \cdot \mathrm{d})\end{array}$}} & \multirow{2}{*}{\multicolumn{2}{|c|}{ Children }} & \multirow{2}{*}{\multicolumn{2}{|c|}{ Adults }} & \multirow{3}{*}{ Children } & \multirow{3}{*}{ Adults } \\
\hline & & & & & & & & & & & & & & \\
\hline & & & & & & & & & \multirow{2}{*}{$\begin{array}{c}\text { As } \\
1.20\end{array}$} & \multirow{2}{*}{$\begin{array}{c}\text { iAs } \\
0.84\end{array}$} & \multirow{2}{*}{$\begin{array}{c}\text { As } \\
0.66\end{array}$} & \multirow{2}{*}{$\begin{array}{c}\text { iAs } \\
0.46\end{array}$} & & \\
\hline & & & 95.77 & 62.20 & 0.36 & 0.25 & 0.20 & 0.14 & & & & & $3.78 \mathrm{E}-04$ & $2.06 \mathrm{E}-04$ \\
\hline & & Zhuzhou-2 & 74.17 & 55.92 & 0.28 & 0.23 & 0.15 & 0.12 & 0.93 & 0.75 & 0.51 & 0.41 & $3.40 \mathrm{E}-04$ & $1.85 \mathrm{E}-04$ \\
\hline & & Zhuzhou-3 & 71.28 & 66.91 & 0.27 & 0.27 & 0.15 & 0.15 & 0.90 & 0.90 & 0.49 & 0.49 & $4.07 \mathrm{E}-04$ & $2.21 \mathrm{E}-04$ \\
\hline & & Zhuzhou-4 & 60.24 & 34.35 & 0.23 & 0.14 & 0.12 & 0.08 & 0.76 & 0.46 & 0.41 & 0.25 & 2.09E-04 & $1.14 \mathrm{E}-04$ \\
\hline & & Chenzhou & 38.52 & 16.12 & 0.15 & 0.07 & 0.08 & 0.04 & 0.48 & 0.22 & 0.26 & 0.12 & 9.79E-05 & 5.33E-05 \\
\hline & \multirow{8}{*}{ Guangdong } & Foshan-2 & 116.95 & 53.97 & 0.44 & 0.22 & 0.24 & 0.12 & 1.47 & 0.73 & 0.80 & 0.40 & $3.28 \mathrm{E}-04$ & $1.79 \mathrm{E}-04$ \\
\hline & & Foshan-3 & 106.90 & 54.09 & 0.40 & 0.22 & 0.22 & 0.12 & 1.34 & 0.73 & 0.73 & 0.40 & $3.29 \mathrm{E}-04$ & $1.79 \mathrm{E}-04$ \\
\hline & & Shaoguan & 53.60 & 37.05 & 0.20 & 0.15 & 0.11 & 0.08 & 0.67 & 0.50 & 0.37 & 0.27 & $2.25 \mathrm{E}-04$ & $1.23 \mathrm{E}-04$ \\
\hline & & Qingyuan & 66.50 & 40.23 & 0.25 & 0.16 & 0.14 & 0.09 & 0.84 & 0.54 & 0.46 & 0.30 & $2.44 \mathrm{E}-04$ & $1.33 \mathrm{E}-04$ \\
\hline & & Guangzhou-1 & 180.11 & 84.44 & 0.68 & 0.34 & 0.37 & 0.19 & 2.26 & 1.14 & 1.23 & 0.62 & $5.13 \mathrm{E}-04$ & $2.79 \mathrm{E}-04$ \\
\hline & & Guangzhou-2 & 135.84 & 99.61 & 0.51 & 0.40 & 0.28 & 0.22 & 1.71 & 1.34 & 0.93 & 0.73 & $6.05 \mathrm{E}-04$ & 3.30E-04 \\
\hline & & Zengcheng & 106.73 & 57.82 & 0.40 & 0.23 & 0.22 & 0.13 & 1.34 & 0.78 & 0.73 & 0.43 & $3.51 \mathrm{E}-04$ & $1.91 \mathrm{E}-04$ \\
\hline & & Zhongshan & 94.88 & 49.43 & 0.36 & 0.20 & 0.19 & 0.11 & 1.19 & 0.67 & 0.65 & 0.36 & $3.00 \mathrm{E}-04$ & $1.64 \mathrm{E}-04$ \\
\hline & \multirow[t]{5}{*}{ Hei Longjiang } & Ha Erbin-2 & 112.21 & 52.35 & 0.42 & 0.21 & 0.23 & 0.12 & 1.41 & 0.71 & 0.77 & 0.39 & $3.18 \mathrm{E}-04$ & $1.73 \mathrm{E}-04$ \\
\hline & & Ha Erbin-3 & 95.76 & 39.75 & 0.36 & 0.16 & 0.20 & 0.09 & 1.20 & 0.54 & 0.66 & 0.29 & $2.42 \mathrm{E}-04$ & $1.32 \mathrm{E}-04$ \\
\hline & & Ha Erbin-4 & 116.22 & 73.72 & 0.44 & 0.30 & 0.24 & 0.16 & 1.46 & 1.00 & 0.80 & 0.54 & $4.48 \mathrm{E}-04$ & $2.44 \mathrm{E}-04$ \\
\hline & & Ha Erbin-5 & 120.99 & 72.70 & 0.46 & 0.29 & 0.25 & 0.16 & 1.52 & 0.98 & 0.83 & 0.53 & $4.42 \mathrm{E}-04$ & $2.41 \mathrm{E}-04$ \\
\hline & & Ha Erbin-6 & 84.91 & 80.41 & 0.32 & 0.33 & 0.17 & 0.18 & 1.07 & 1.09 & 0.58 & 0.59 & 4.89E-04 & $2.66 \mathrm{E}-04$ \\
\hline & \multirow[t]{5}{*}{ Hubei } & Jingmen-1 & 140.16 & 105.67 & 0.53 & 0.43 & 0.29 & 0.23 & 1.76 & 1.43 & 0.96 & 0.78 & $6.42 \mathrm{E}-04$ & $3.50 \mathrm{E}-04$ \\
\hline & & Jingmen-2 & 80.58 & 85.86 & 0.30 & 0.35 & 0.17 & 0.19 & 1.01 & 1.16 & 0.55 & 0.63 & $5.22 \mathrm{E}-04$ & $2.84 \mathrm{E}-04$ \\
\hline & & Xiantao-1 & 109.89 & 63.31 & 0.41 & 0.26 & 0.23 & 0.14 & 1.38 & 0.85 & 0.75 & 0.47 & $3.85 \mathrm{E}-04$ & $2.10 \mathrm{E}-04$ \\
\hline & & Xiantao-2 & 78.97 & 70.95 & 0.30 & 0.29 & 0.16 & 0.16 & 0.99 & 0.96 & 0.54 & 0.52 & $4.31 \mathrm{E}-04$ & 2.35E-04 \\
\hline & & Xiantao-3 & 81.32 & 62.97 & 0.31 & 0.26 & 0.17 & 0.14 & 1.02 & 0.85 & 0.56 & 0.46 & 3.83E-04 & $2.08 \mathrm{E}-04$ \\
\hline & \multirow[t]{2}{*}{ Other Country } & Japan-1 & 57.54 & 43.12 & 0.22 & 0.17 & 0.12 & 0.10 & 0.72 & 0.58 & 0.39 & 0.32 & $2.62 \mathrm{E}-04$ & $1.43 \mathrm{E}-04$ \\
\hline & & Japan-2 & 86.33 & 74.71 & 0.33 & 0.30 & 0.18 & 0.16 & 1.08 & 1.01 & 0.59 & 0.55 & $4.54 \mathrm{E}-04$ & $2.47 \mathrm{E}-04$ \\
\hline
\end{tabular}

Table 6. Health risk assessment of As in rice steamed under high pressure to children and adults.

ADD-As ADD-iAs ADD-As ADD-iAs

\begin{tabular}{|c|c|c|c|c|c|c|c|c|c|c|c|c|c|c|}
\hline \multirow{3}{*}{ High } & & & \multirow{2}{*}{$\begin{array}{l}\text { Total As } \\
(\mu \mathrm{g} / \mathrm{kg})\end{array}$} & \multirow{2}{*}{$\begin{array}{c}\text { iAs } \\
(\mu \mathrm{g} / \mathrm{kg})\end{array}$} & \multirow{2}{*}{\multicolumn{2}{|c|}{$\begin{array}{l}\text { Children } \\
(\mu \mathrm{g} / \mathrm{kg} \cdot \mathrm{d})\end{array}$}} & \multirow{2}{*}{\multicolumn{2}{|c|}{$\begin{array}{c}\text { Adults } \\
(\mu \mathrm{g} / \mathrm{kg} \cdot \mathrm{d})\end{array}$}} & \multicolumn{2}{|c|}{ Children } & \multicolumn{2}{|c|}{ Adults } & \multirow[t]{2}{*}{ Children } & \multirow[t]{2}{*}{ Adults } \\
\hline & & & & & & & & & As & iAs & As & iAs & & \\
\hline & \multirow[t]{5}{*}{ Hunan } & Zhuzhou-1 & 80.69 & 55.74 & 0.36 & 0.25 & 0.19 & 0.13 & 1.18 & 0.82 & 0.64 & 0.45 & $3.69 \mathrm{E}-04$ & $2.01 \mathrm{E}-04$ \\
\hline \multirow{24}{*}{$\begin{array}{l}\text { Pressure } \\
\text { Steamed }\end{array}$} & & Zhuzhou-2 & 62.49 & 50.12 & 0.28 & 0.22 & 0.15 & 0.12 & 0.92 & 0.74 & 0.50 & 0.40 & 3.32E-04 & $1.81 \mathrm{E}-04$ \\
\hline & & Zhuzhou-3 & 60.05 & 59.97 & 0.26 & 0.26 & 0.14 & 0.14 & 0.88 & 0.88 & 0.48 & 0.48 & $3.97 \mathrm{E}-04$ & $2.16 \mathrm{E}-04$ \\
\hline & & Zhuzhou-4 & 50.75 & 30.79 & 0.22 & 0.14 & 0.12 & 0.07 & 0.74 & 0.45 & 0.41 & 0.25 & $2.04 \mathrm{E}-04$ & $1.11 \mathrm{E}-04$ \\
\hline & & Chenzhou & 32.45 & 14.44 & 0.14 & 0.06 & 0.08 & 0.03 & 0.48 & 0.21 & 0.26 & 0.12 & $9.57 \mathrm{E}-05$ & $5.21 \mathrm{E}-05$ \\
\hline & Guangdong & Foshan-2 & 98.53 & 48.37 & 0.43 & 0.21 & 0.24 & 0.12 & 1.45 & 0.71 & 0.79 & 0.39 & $3.20 \mathrm{E}-04$ & $1.75 \mathrm{E}-04$ \\
\hline & & Foshan-3 & 90.07 & 48.47 & 0.40 & 0.21 & 0.22 & 0.12 & 1.32 & 0.71 & 0.72 & 0.39 & $3.21 \mathrm{E}-04$ & $1.75 \mathrm{E}-04$ \\
\hline & & Shaoguan & 45.16 & 33.21 & 0.20 & 0.15 & 0.11 & 0.08 & 0.66 & 0.49 & 0.36 & 0.27 & $2.20 \mathrm{E}-04$ & $1.20 \mathrm{E}-04$ \\
\hline & & Qingyuan & 56.03 & 36.05 & 0.25 & 0.16 & 0.13 & 0.09 & 0.82 & 0.53 & 0.45 & 0.29 & 2.39E-04 & $1.30 \mathrm{E}-04$ \\
\hline & & Guangzhou-1 & 151.74 & 75.68 & 0.67 & 0.33 & 0.36 & 0.18 & 2.23 & 1.11 & 1.21 & 0.61 & $5.01 \mathrm{E}-04$ & $2.73 \mathrm{E}-04$ \\
\hline & & Guangzhou-2 & 114.45 & 89.27 & 0.50 & 0.39 & 0.27 & 0.21 & 1.68 & 1.31 & 0.91 & 0.72 & $5.91 \mathrm{E}-04$ & $3.22 \mathrm{E}-04$ \\
\hline & & Zengcheng & 89.92 & 51.82 & 0.40 & 0.23 & 0.22 & 0.12 & 1.32 & 0.76 & 0.72 & 0.42 & $3.43 \mathrm{E}-04$ & 1.87E-04 \\
\hline & & Zhongshan & 79.94 & 44.30 & 0.35 & 0.20 & 0.19 & 0.11 & 1.17 & 0.65 & 0.64 & 0.36 & 2.93E-04 & $1.60 \mathrm{E}-04$ \\
\hline & Hei Longjiang & Ha Erbin-2 & 94.54 & 46.92 & 0.42 & 0.21 & 0.23 & 0.11 & 1.39 & 0.69 & 0.76 & 0.38 & $3.11 \mathrm{E}-04$ & $1.69 \mathrm{E}-04$ \\
\hline & & Ha Erbin-3 & 80.68 & 35.63 & 0.36 & 0.16 & 0.19 & 0.09 & 1.18 & 0.52 & 0.64 & 0.29 & $2.36 \mathrm{E}-04$ & $1.29 \mathrm{E}-04$ \\
\hline & & Ha Erbin-4 & 97.92 & 66.07 & 0.43 & 0.29 & 0.23 & 0.16 & 1.44 & 0.97 & 0.78 & 0.53 & $4.38 \mathrm{E}-04$ & $2.38 \mathrm{E}-04$ \\
\hline & & Ha Erbin-5 & 101.94 & 65.16 & 0.45 & 0.29 & 0.24 & 0.16 & 1.50 & 0.96 & 0.81 & 0.52 & 4.32E-04 & $2.35 \mathrm{E}-04$ \\
\hline & & Ha Erbin-6 & 71.54 & 72.07 & 0.31 & 0.32 & 0.17 & 0.17 & 1.05 & 1.06 & 0.57 & 0.58 & $4.77 \mathrm{E}-04$ & $2.60 \mathrm{E}-04$ \\
\hline & Hubei & Jingmen-1 & 118.09 & 94.71 & 0.52 & 0.42 & 0.28 & 0.23 & 1.73 & 1.39 & 0.94 & 0.76 & $6.27 \mathrm{E}-04$ & $3.42 \mathrm{E}-04$ \\
\hline & & Jingmen-2 & 67.89 & 76.95 & 0.30 & 0.34 & 0.16 & 0.19 & 1.00 & 1.13 & 0.54 & 0.62 & $5.10 \mathrm{E}-04$ & $2.78 \mathrm{E}-04$ \\
\hline & & Xiantao-1 & 92.58 & 56.74 & 0.41 & 0.25 & 0.22 & 0.14 & 1.36 & 0.84 & 0.74 & 0.45 & $3.76 \mathrm{E}-04$ & $2.05 E-04$ \\
\hline & & Xiantao-2 & 66.53 & 63.59 & 0.29 & 0.28 & 0.16 & 0.15 & 0.98 & 0.94 & 0.53 & 0.51 & $4.21 \mathrm{E}-04$ & $2.29 \mathrm{E}-04$ \\
\hline & & Xiantao-3 & 68.51 & 56.44 & 0.30 & 0.25 & 0.16 & 0.14 & 1.01 & 0.83 & 0.55 & 0.45 & $3.74 \mathrm{E}-04$ & $2.04 \mathrm{E}-04$ \\
\hline & Other Country & Japan-1 & 48.48 & 38.65 & 0.21 & 0.17 & 0.12 & 0.09 & 0.71 & 0.57 & 0.39 & 0.31 & $2.56 \mathrm{E}-04$ & $1.39 \mathrm{E}-04$ \\
\hline & & Japan-2 & 72.73 & 66.96 & 0.32 & 0.30 & 0.17 & 0.16 & 1.07 & 0.99 & 0.58 & 0.54 & $4.43 \mathrm{E}-04$ & $2.42 \mathrm{E}-04$ \\
\hline
\end{tabular}

\section{Figures}




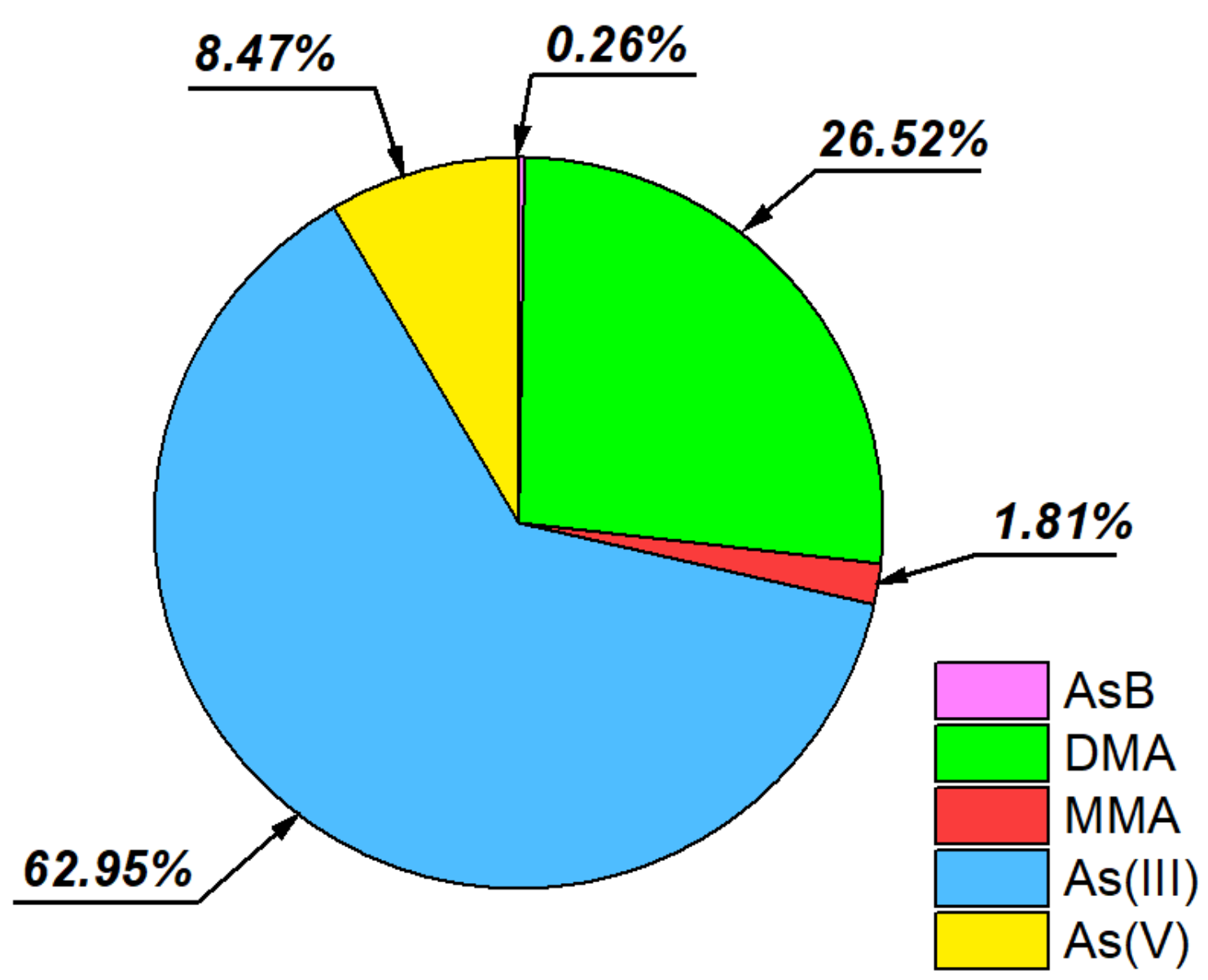

Figure 1

Composition of As and average percentage of each speciation in rice samples of 31 samples. 


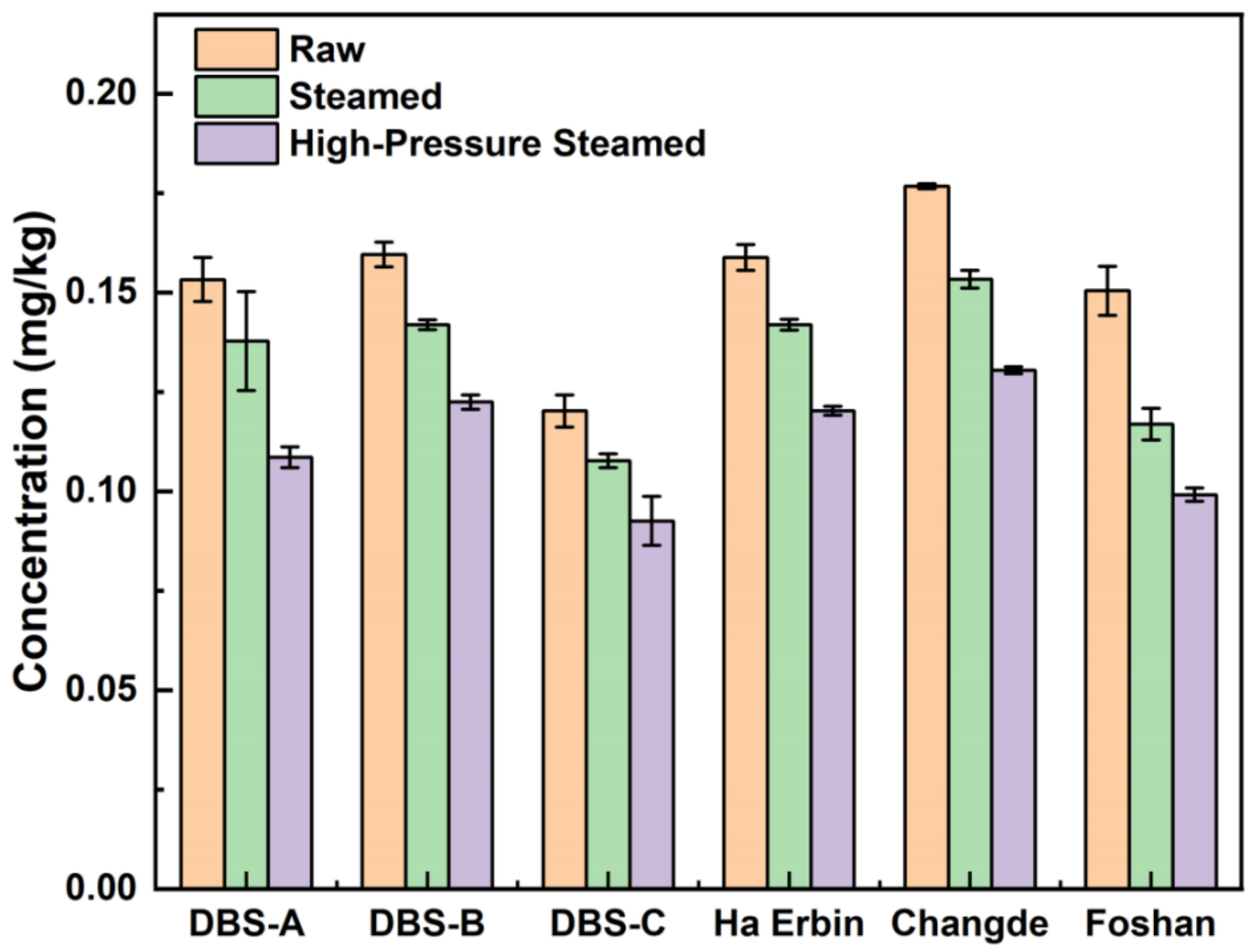

Figure 2

Graphical comparison of total As concentration between six selected regions and cooking methods. 


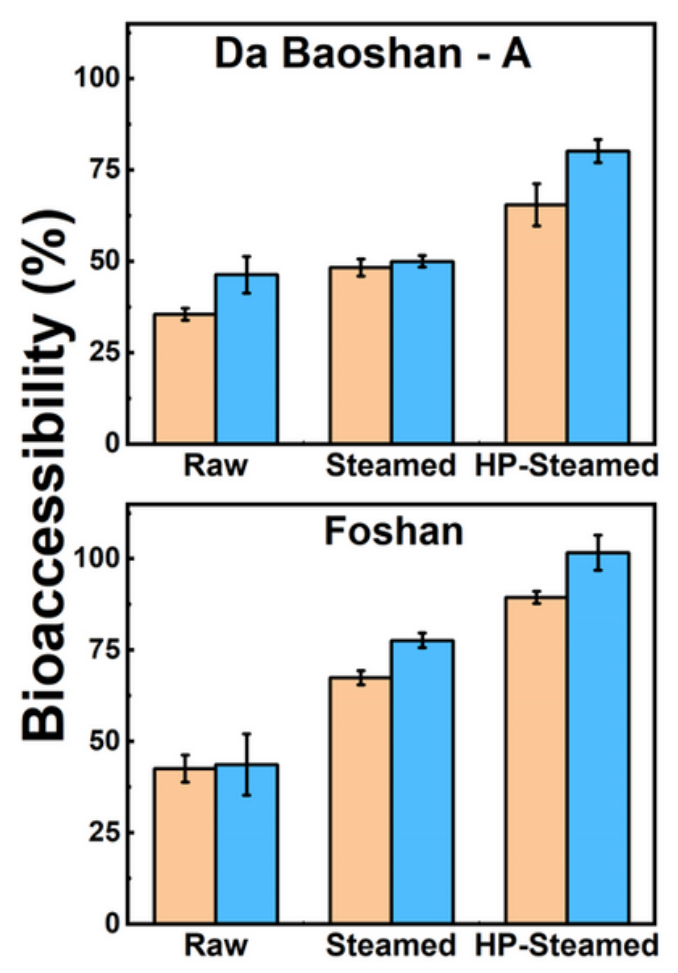

Gastric $\square$ Small Intestinal
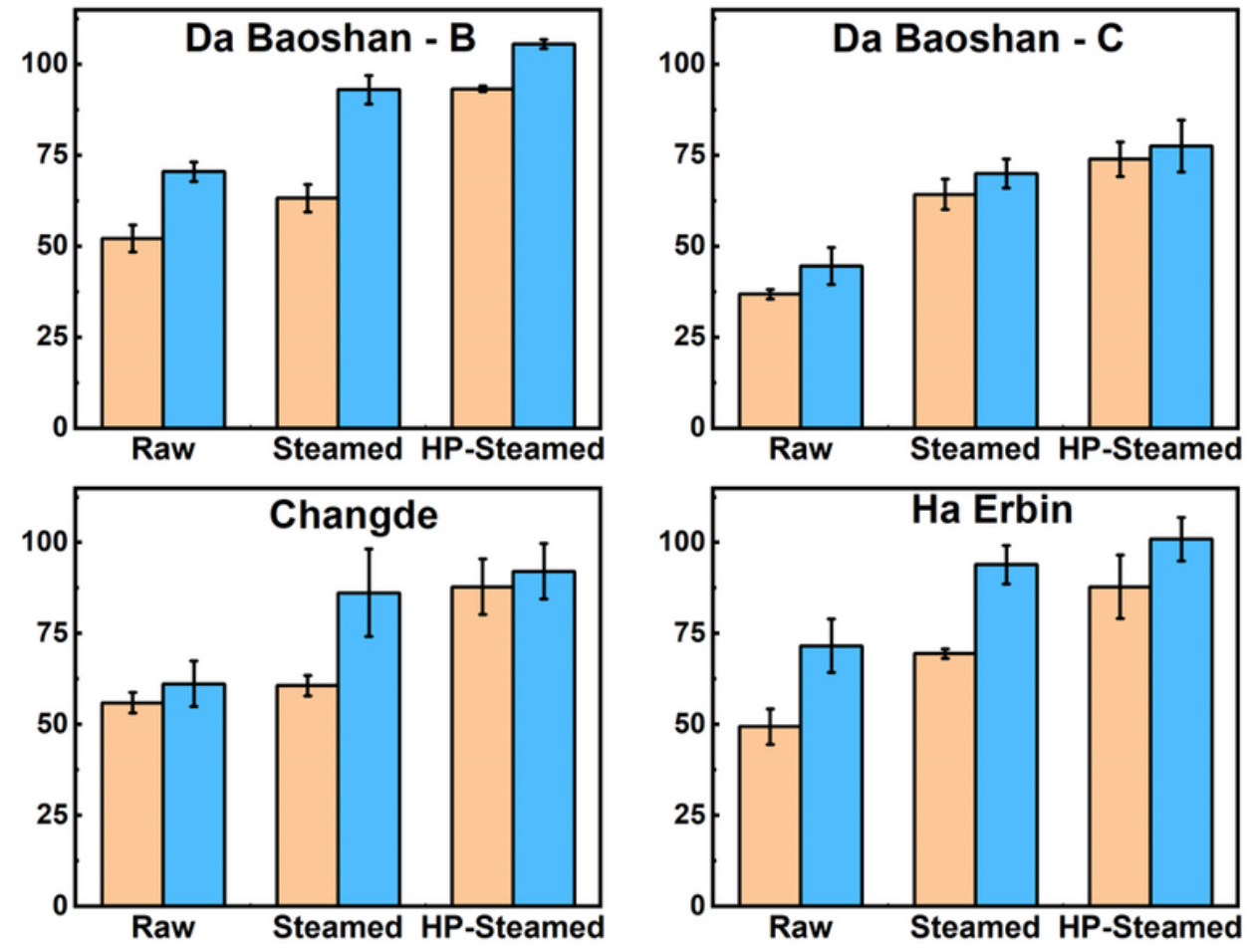

Figure 3

Bioaccessibility of As in rice samples of six selected regions treated with different cooking methods.

AsC As(V) As(III) MMA DMA AsB
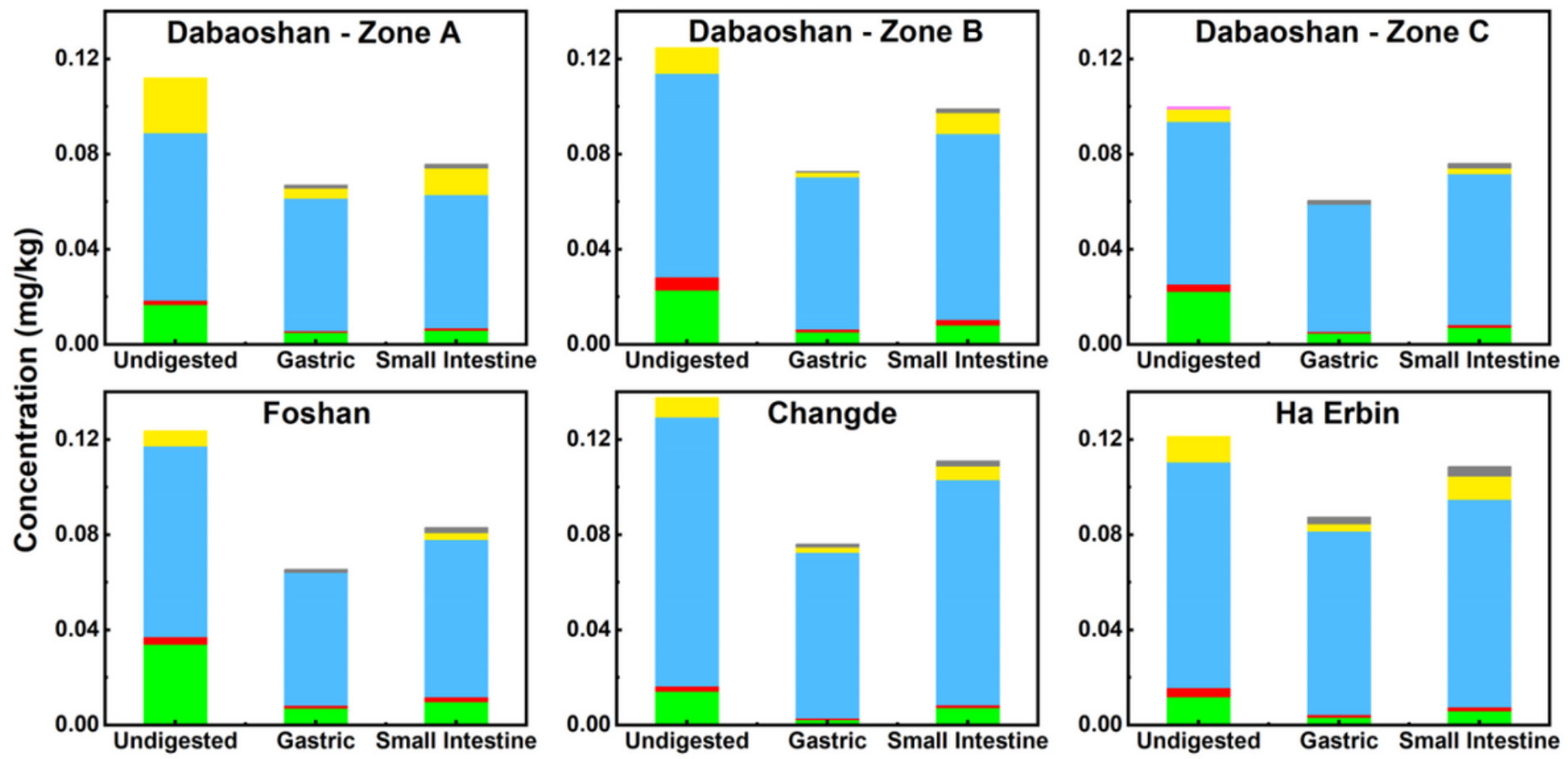

Figure 4

Arsenic speciation in steamed rice of six selected regions after different digestion stages. 

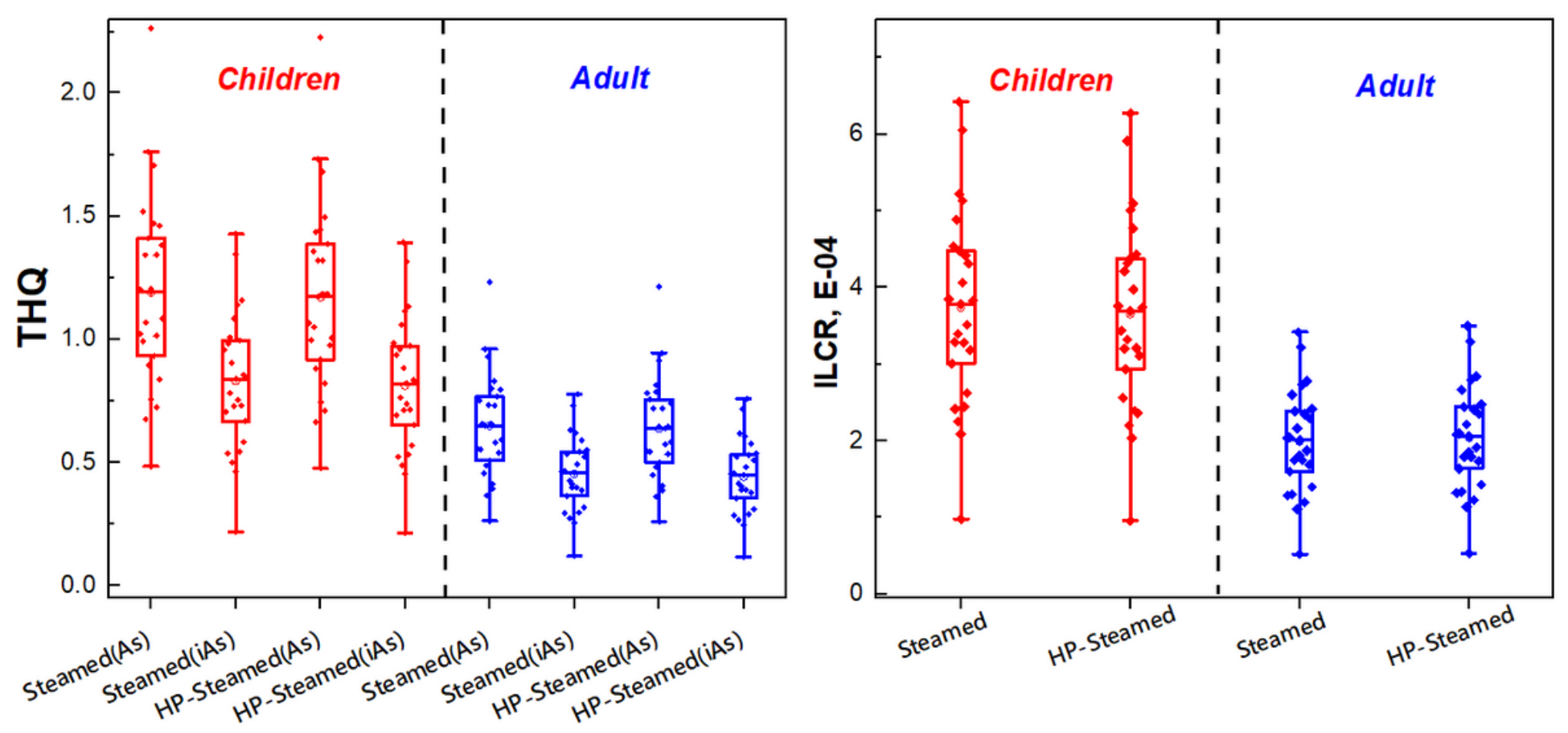

Figure 5

Comparison of THQ and ILCR of As in 25 rice samples between children and adults 